\title{
The Policy For Ambulance Service Quality During The Covid-19 Pandemic Era In Bandung City (A Study By Using Catwoe Approach)
}

\author{
Endang Wirjatmi Trilestari ${ }^{1}$, Eka Nugraha ${ }^{2}$, Saekul Anwar ${ }^{3}$ \\ \{endang.wirjatmi@poltek.stialanbandung.ac.id; mreanugrah@gmail.com; thesay05@gmail.com\} \\ ${ }^{123}$ Polytechnic of STIA LAN Bandung
}

\begin{abstract}
This study aims to solve the problem of meeting the needs of quality ambulance services. The policy for ambulance services in the Covid-19 pandemic era have become a very crucial need. The problem of quality ambulance services in urban areas is felt by the community. Fulfilling very limited service needs along with the ups and downs of the number of Covid-19 sufferers has become a limitation of service providers. This research was carried out by using a soft systems methodology approach by focusing on the problem using CATWOE because the complexity of the service quality can be felt by various parties, including customers who are ambulance service users, and actors as policy makers. Moreover, the service process has a greater impact on service quality, especially for Covid19 patients, as its transformation. The impact of the service was explored using a world view. These elements can provide a comprehensive overview of the service owner and the environment constraints. The Bandung city was chosen because it is the capital city of West Java Province, which has a very dense population, and experiences a red zone against covid 19. However, Bandung city has adequate hospital and hotel or lodging facilities for handling COVID-19.
\end{abstract}

Keywords: Policy, service, CATWOE, Ambulance

\section{Background}

The Corona 19 pandemic, which was declared an epidemic by WHO on January 30, 2020, has since made major changes to the lives of the world's people. This can be learned from the various news that we read, see and hear from various media. This Covid-19 pandemic has taught us all a lesson that many people are afraid and suspicious of their friends, family and anyone (Akanksha Mandal:2021), and this is a disaster that has hit the world. This experience also happened in Bandung city. The dynamic development of the spread of Covid 19 is very high, causing public demands for high services to keep increasing. The results of research conducted by Muchammad Iqbal Firmansyah, Cs.(2020) illustrated the low level of service in handling covid 19.

This research was seen from the readiness in medical services in handling covid 19. The quality of public services, on the other hand, makes people also experience clinical depression. This is because of mood or feeling disturbances experienced by the community. (Akanksha Mandal: 2021). This condition causes the need for any protection and services in a panic 
situation. Meanwhile, the public does not yet have the correct understanding and clear mechanism on how to prevent COVID-19. (Wahyu Sulistiadi, Sri Rahayu, Nanny Harmani, 2021).

One of the most crucial services in the COVID-19 pandemic is transportation services for people exposed to Covid 19. Transportation for the sick is an ambulance. People want very fast service. The problem of the quality of ambulance services in urban areas is felt by the community. Fulfilling very limited service needs along with the ups and downs of the number of Covid-19 sufferers has become a limitation for service providers.

Dr. James Watt (2021) director of medical services in Scotland said that the ambulance service in the era of covid 19 introduced a different and unique situation that became a new challenge. However, this is a trigger in an effort to provide fast and effective service. The limitations of the above services are a challenge for medical personnel and other equipment. The challenge is the increasing number of cases of the spread of covid 19 from day to day as shown in the following graph:

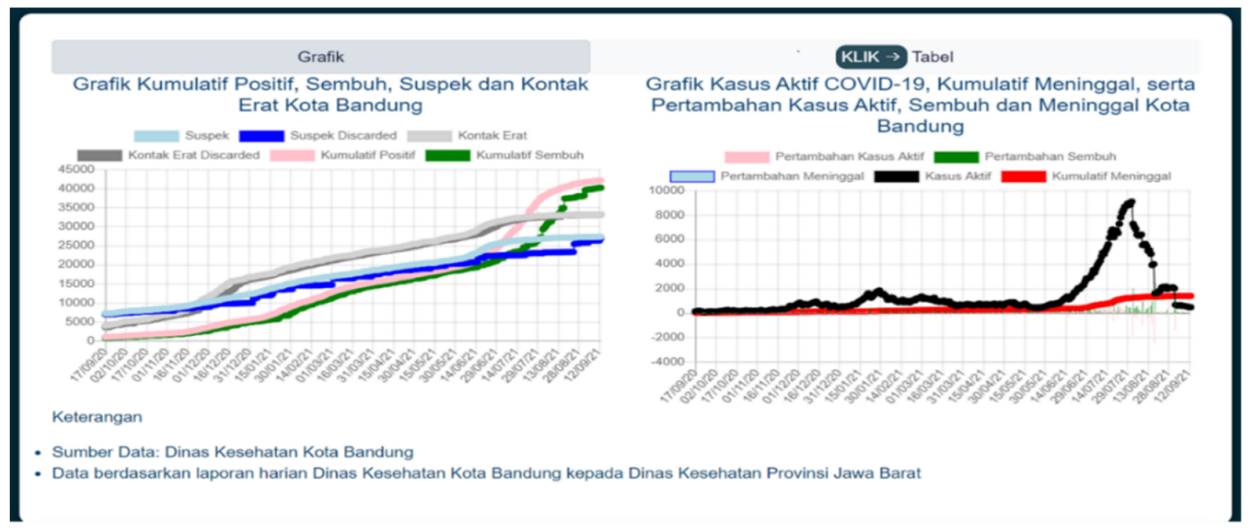

As the number of people infected with COVID-19 tends to increase, as the data above shows, the need for ambulance services as a means of transportation for people infected with COVID-19 is also increasing. With the assumption of the problems above, this study intends to demonstrate and solve the problem of the demand for quality ambulance services.

\section{The need for quality service}

The quality of public services, which is often expressed in various works of literature and research, generally uses theories to measure private services, as expressed by Parasuraman, Zeithaml \& Berry, (1991); Parasuraman et al., (1988). Quality measures used include indicators of tangible, Empathy, Reliability, Responsiveness, and Assurance. However, this indicator is still a measure that is currently still being used in public services.

Guenoun et al., (2016) revealed a model of the quality of public services from 2 (two) perspectives, namely the expectations of service recipients with confirmed reality and the performance of the service itself. However, during the Covid 19 Pandemic, where people panicked in obtaining services, these indicators are neglected. Parasuraman (1988) with the service quality theory with the ServQual dimensions above and Guenoun et.al (2016) provided quality service signs from a tangible point of view in ambulance services, which are physical from the ambulance itself. 
The five dimensions of ServQual in ambulance services during the COVID-19 pandemic defined Tangibles as the physical facility of an ambulance that is used as transportation for patients infected with Covid 19. Reliability is the ability and reliability to provide reliable services, meaning the provision of ambulances promptly. Ready-to-use condition with drivers who are ready to serve with the covid 19 protocol. Responsiveness is the ability to help and provide services quickly and accurately, as well as responsiveness to consumer desires. Another aspect of service quality is assurance.

Assurance is the ability of ambulance service providers in handling COVID-19 which describes the level of trust of patients and their families. It includes the skills and friendliness and courtesy of employees in ensuring consumer confidence, in this case, patients and their families. The empathy aspect includes the attitude of the ambulance service providers who are ready to serve firmly but attentively from employees to consumers.

In the transportation service for people exposed to COVID-19, of course, it requires its requirements where the service is not only with service quality measures as in business (Parasuraman; Guanon 2016) above. The aspects of service quality above are generally used to determine service quality. Each country has its own service standards. Just as in the UK, there are special service standards for ambulances for covid 19. Especially for ambulance services for covid 19 patients in the UK, they have their service standards, including initial observation by identifying cases of covid 19 patients; standards for infection prevention and control measures; personal protective standards for both the infected community and service providers; standard procedures for using aerosols (APG) that can be used effectively; clinical applications or socalled clinical treatments that have been standardized for use by the whole community; procedures for delivery and acceptance of patients from family to hospital or from the hospital to the family when the patient has been declared cured; and decontamination for both medical and paramedical personnel as well as for the patients themselves.

Meanwhile in Indonesia recently, all public services were given quality standard guidelines in a policy, namely Law No. 25 of 2009, and the indicators are determined by the criteria used to assess the quality of public services by regarding the Decree of the ministry of the administrative state apparatus (Menpan) No. 81 of 1993 as follows: (1) The number of residents/communities requesting services and the development of services from time to time. (2) The length of time the service is provided. (3) Ratio/comparison between the number of existing employees/staff with the number of residents/community requesting services to show the level of work productivity. (4) The use of modern tools to speed up and simplify the implementation. (5) The frequency of complaints and/or praise from the public regarding the performance of the services provided, either through the mass media or through the suggestion box provided. (6) Other physical assessments, such as environmental cleanliness and coolness, employee work motivation and other aspects that have a direct influence on the quality of public services. Based on the above policies, each local government makes its own guidelines for the use of ambulances.

\section{Method}

This research was conducted using a soft system methodology approach proposed by Peter M. Checland through Customer, Actors, Transformation, World view, Owner, and Environmental (CATWOE). To elaborate CATWOE, with the analysis perspective, Customers, in this case, are Covid 19 Sufferers (their family), who need ambulance services; Actors, in this case, are ambulance service providers who are involved in implementing the solutions taken, to influence the success of ambulance services; transformation here is how the policies, procedures, and processes must be carried out to influence the success of the service; 
world view is an overall picture and impact of service quality; Owner is a researcher who helps in solving problems related to policies for quality ambulance services; and Environmental is used to see the complexity of the problem areas that become obstacles and will affect the solution.

The steps that were carried out in Soft Systems Methodology were as follows: First, looking at the complexity of the problem in general, unstructured; second, comparing the phenomenon of the developing problem to be studied with the phenomenon and problem-solving from the same cases; third, formulating the problem related to the lack quality of ambulance services during the Covid-19 pandemic which was is done by Brainstorming with Customers, in this case, are patients and their families who need ambulance services.

Besides that, the owner is also followed by the policymakers in the ambulance service for patients with covid 19. The fourth step is to analyze the answers to the questions developed through the CATWOE. The fifth step is to compare the answers to questions and information obtained from both oral and secondary data obtained from research results. Then the seventh step compares the theory with the concepts used, to produce a standard system behavior pattern and then determine the behavior of the system regarding the policies that will be carried out to address the need for quality ambulance services.

\section{Findings and Discussion}

In the aspect of customers. It was found that the growth of covid patients was fluctuating and dynamic, those who need ambulance services also experienced the same movement. Results of research conducted by Research Dive New York, USA, May 31, 2021 (GLOBE NEWSWIRE) Globally Predicted to See Extensive Growth in the COVID-19 Pandemic due to Rising Demand for Emergency Health Services. Likewise in Bandung city, In general, patients who need an ambulance are patients in critical condition, so the speed of service is a major requirement.

Until May 2021, the addition of the number of Covid patients reached an average of 78 people per day. While the addition of the number of patients treated per day at least 15 people. From the results of in-depth interviews conducted with both patients and their families, they generally do not know information about service centers. The patient's panic condition makes it limited were to ask for help. Even not all patients in Bandung city get ambulance services and are forced to go to the hospital using private vehicles.

The element of reliability required by Parasuraman (1988) for customers is felt to be inadequate because the transformation of changes in service demands in the era of the COVID19 pandemic for owners who have authority in ambulance services still provides a slow response. The results of interviews with the patient community on average stated that they could not contact the officers (actors) when the community needed help. If the patient received a welcome when he needed help, the officers (actors) did not come. Why does this happen?

Actors, in this case, are ambulance service providers, consisting of managers and ambulance service officers stated the complexity and obstacles faced in ambulance services. The complexity faced is that covid 19 is considered a dangerous virus, because of the ease of transmission. This condition becomes doubt for officers in serving, even though the health protocol has been made and known. This has also become a policy in the use of ambulances with certain standards.

However, there was no Standard Operating Procedure for the use of special ambulances to handle Covid 19 patients. The presence of Covid 19 has caused panic in ambulance services. This has created self-regulation (altruism) that is carried out outside the existing Policy. For 
example, an ambulance is used simultaneously from those in Bandung city to cope with the transportation needs of the sick.

The transformation is done by accident. Changes in the speed of ambulance services are carried out without any regulation. The element that provides reinforcement is the commitment that every COVID-19 patient who needs services can be fulfilled immediately. Commitment is the key word for their determination to help the community. So that procedural setting are ignored. This is also experienced by various countries, and it is recommended that we evacuate the deceased using a hearse. There are 83 ambulances in the city of Bandung, but only 15 ambulances can evacuate COVID-19 patients.

On average, the evacuation of each patient takes 3 hours and after evacuating the patient, the ambulance must be cleaned/sterilized which takes 3 hours as well. Therefore, it is expected that every day 3 patients can be evacuated. However, from the results of interviews with the service provider owner or the owner of the ambulance service policy, he stated that he could not meet the needs in accordance with the established standards. This is because the time used for evacuation when the patient will enter the hospital is too long. These standards often cannot be met properly.

However, during the peak of the pandemic, ambulances were unable to evacuate, so they used ambulances which are usually used to evacuate patients. This is different from what happened in India. India is developing patient evacuation by air to speed up services. This is an inadequate transformation of service providers (owners) in serving COVID-19 patients. The owner's side admits that there has been no development of an adequate ambulance supply during the COVID-19 pandemic.

World view was done by looking at the resources that are around, namely the existence of an ambulance owned by the community that can be used together. As stated above, commitment/commitment to serve is a shared value. The condition of the ambulance service in handling Covid 19 in the city of Bandung is a mainstay for other regions because the city of Bandung is the destination for asking for help in critical conditions. Bandung city has 30 hospitals.

In a situation like this, it provides an opportunity for the community to participate in providing ambulances. As is the case with the Exclusive Report which states that the Global Ambulance Services Market is Predicted to Witness Widespread Growth in COVID-19 Pandemic due to Growing Demand for Emergency Healthcare Services - Strategic Technological Innovations, During the Covid-19 Outbreak, To Promote Global Ambulance Services Market Development.

Environmental, conditions in the city of Bandung is the capital of the province of West Java which has been formed by the Netherlands so that the number of hospitals that serve the obstacles faced in realizing a quality ambulance service is the environment around the patient. The environment in this case is the attitude of the community. The attitude of the community during the pandemic is in a state of panic. (Akanksha Mandal:2021) In general, in anticipating changes in services, it is necessary to have a new flexible policy in ambulance services, collaboration between the community, government and the United private sector in its provision. This also provides an opportunity for the community to participate in contributing to the provision of ambulance services.

\section{Closing}

Ambulance services must be able to transform in line with the very fast and dynamic Covid19 pandemic conditions, the increasing number of requests and demands for good service 
quality must be able to be provided by service providers. Commitment to service is the keyword for their determination to help the community so that various obstacles found during the service process can be resolved properly.

The use of CATWOE can figure out a broader analysis of the problems and obstacles in optimizing the ambulance service proposed by the writer. The demands of the community as customers have not been fulfilled in accordance with the service standard policy. This is due to limited facilities that are not followed by a policy of community participation in ambulance services.

\section{Recommendation}

To maintain the commitment that was built due to an emergency, it is necessary to provide control guidance as the current ambulance service policy does not have a standard operating procedure. The pattern of collaborative relations between the government, the private sector, and the community needs to be confirmed as an operational policy for emergency ambulance services. Opening opportunities for collaboration with the community to meet the needs of ambulance services is also needed. This will bring a double impact on the community, namely providing business opportunities and meeting the needs of the community for ambulance services with adequate standards.

\section{References}

[1] Akanksha Mandal, Psychological Aspects In Terms Of Physical, Mental And Sociological Factors During Worldwide Corona Crisis; Indian Journal Of Forensic Medicine \& Toxicology, April-June 2021, Vol. 15, No. 2

[2] Checkland, P. \& Scholes, J. (1990). Soft Systems Methodology In Action.Chichester: John Wiley \& Sons Ltd.

[3] Checkland, Peter.(2000), Soft System Methodology: A Thirty Year Retrospective, System Research And Behavioral Science, 17, S11-S58

[4] Wahyu Sulistiadi, Sri Rahayu, Nanny Harmani(2020): Handling Of Public Stigma On COVID-19 In Indonesian Society : Jurnal Kesehatan Masyarakat Nasional (National Public Health); Journal). 2020; Special Issue 1: 70-76 DOI: 10.21109/Kesmas.V15i2.3909

[5] Muchammad Iqbal Firmansyah, Fajar Rahmanto, Deni Setyawan (2020), THE PREPAREDNESS FOR THE COVID-19 PANDEMIC MANAGEMENT IN INDONESIA, Jurnal Administrasi Kesehatan Indonesia Volume 8 No 2 December 2020 Published By Universitas Airlangga Doi: 10.20473/Jaki.V8i2.2020.188-201

[6] Guidance-Covid 19-: Guidense For Covid-19: Guidene For Ambulance Serviced, (2021) Https:/Www.Gov.Uk/Government/Publications/Covid-19-Guidance-For-AmbulanceTrusts/Covid-19-Guidance-For-Ambulance-Trusts; Updated 19 July 2021

[7] Lauri Laukkanen, Sanna Lahtinen, Janne Liisanantti, Timo Kaakinen, Ari Ehrola, Lasse Raatiniemi Early Impact Of The COVID-19 Pandemic And Social Restrictions On Ambulance Missions European Journal Of Public Health, Ckab065, Https://Doi.Org/10.1093/Eurpub/Ckab065; Published: 10 May 2021

[8] Global Ambulance Services Market Predicted To Witness Widespread Growth In COVID-19 Pandemic Due To Growing Demand For Emergency Healthcare Services - Exclusive Report [Pages250] By Research Dive May 31, 2021 09:10 ET 